\title{
Development of a Novel In-vitro Protocol for Micro propagation of Tomato Male Sterile Line (Shalimar FMS-1) of Kashmir Valley India
}

\author{
Syed Mazahir Hussain ${ }^{1 *}$, Khursheed Hussain ${ }^{1}$, Ajaz Ahmad Malik ${ }^{1}$, \\ Amjad M. Hussaini ${ }^{2}$, Syeda Farwah ${ }^{1}$, Majid Rashid ${ }^{1}$ and Rauoof Ahmad \\ Rather $^{3}$ \\ ${ }^{1}$ Division of Vegetable Science, Sher-e-Kashmir University of Agricultural Sciences \\ and Technology of Kashmir, Shalimar, Srinagar, Jammu and Kashmir, India \\ ${ }^{2}$ Genome Engineering Laboratory, Division of Plant Biotechnology, Sher-e-Kashmir \\ University of Agricultural Sciences and Technology of Kashmir, Shalimar, Srinagar, \\ Jammu and Kashmir, India \\ ${ }^{3}$ Division of Environmental Science, Sher-e-Kashmir University of Agricultural \\ Sciences and Technology of Kashmir, Shalimar, Srinagar, Jammu and Kashmir, \\ India \\ *Corresponding Author: Syed Mazahir , Division of Vegetable Science, \\ SKUAST-Kashmir, Shalimar, Srinagar, Jammu \& Kashmir, India.
}

\section{Received: March 03, 2021}

Published: March 16, 2021

(C) All rights are reserved by Rauoof Ahmad

Rather., et al.

\begin{abstract}
The present study aimed to develop a novel, efficient and cost effective protocol for in-vitro micro propagation of tomato male sterile line and consisted of two experiments viz., Standardization of protocol for sterilizing the explants for in vitro micro propagation of tomato male sterile line (Shalimar FMS-1) and development of protocol for in vitro shoot and root regeneration in tomato male sterile line in a single medium. Among various sterilization treatments, sodium hypochlorite (1.0\%) for 45 seconds showed the highest survival percentage of explants (100\% for hypocotyl and $91.66 \%$ for single node cutting) and minimum contamination (16.17\% for hypocotyl and $17.22 \%$ in case of single node cutting). Among twenty-seven modified MS media treatment combinations, the treatment combination T-14 (MS medium supplemented with calcium D pantothenate $2 \mathrm{mg} \mathrm{l}^{-1}+$ calcium chloride 440 mg $\mathrm{l}^{-1}+\mathrm{gibberillic}^{-}$ acid $0.4 \mathrm{mg} \mathrm{l}^{-1}$ ) resulted in maximum root and shoot regeneration, recorded maximum shoot and root length. The protocol developed is therefore proposed for micropropagation of tomato male sterile line Shalimar FMS- 1 from the tomato explants in a single modified MS medium overcoming the requirement of two MS media, one for root regeneration and the other for shoot regeneration thus saving more than $50 \%$ of the time and media required for microplant regeneration This protocol overcomes the inefficient, expansive, time consuming and cumbersome nature of already available protocols which require two media (rooting and shooting media) while this proposed protocol ensures complete root and shoot regeneration from an explant (single node cutting/ hypocotyl) in a single modified MS medium.
\end{abstract}

Keywords: Hypocotyl; Microplant; Sterilization; Single Node Cutting; Tomato 


\section{Introduction}

Tomato (Solanum lycopersicum L.), $(2 n=2 \times=24)$ belonging to family Solanaceae an important commercial vegetable crop grown across the globe. The crop is world's largest vegetable crop after potato and sweet potato in area and production and tops the list of canned vegetables. The total global area under tomato is $4.78 \mathrm{mil}-$ lion hectares with a yearly production of 177 million metric tonnes [1]. In India it is grown on an area of 789 thousand hectares with annual production of 19759 thousand metric tonnes [1]. In Jammu and Kashmir State, it is grown over an area of 2.28 thousand hectares with an annual production of 52.96 thousand metric tonnes [2].

Even though India is the second largest tomato producer in the world next to China, its productivity lies far below the average productivity due to number of reasons ranging from climatic conditions to technologies employed in crop management but the most important being the non-availability of high yielding varieties/hybrids suitable to a particular region. Hybrids have spread over the entire world and appear to be the primary reason for high productivity. However, there are several constraints in hybrid adoption; the main factor is high cost of hybrid seed as production of hybrid seed involves skilled labour for manual emasculation and pollination. The use of male sterile lines avoids manual emasculation reduces the labour and cost necessary for $F_{1}$ hybrid seed production.

The maintenance of functional male sterile line in field is difficult, laborious and costly as it involves forced self-pollination for its maintenance which involves removal of anthredial cone and artificial pollination. To overcome this laborious process, tissue culture is an ideal alternative. Available literature shows that the regeneration protocols have been made available for cultivated tomato using different explants viz., cotyledons, hypocotyl, leaf, pedicel, peduncle, stem sections and inflorescence for organogenesis employing different plant growth regulators and requirement of two types of MS media, one for shoot regeneration and thereafter subsequent transfer of regenerated shoot to other type of MS media for root regeneration which is quite cumbersome and extremely time consuming. This study reports for the first time a novel highly efficient modified MS media for microplant regeneration in tomato male sterile line Shalimar FMS-1.

\section{Materials and Methods}

The present investigation on studies on micro propagation of tomato male sterile line (Shalimar FMS-1) was carried out in the Tissue Culture Laboratory, Division of Vegetable Science, and Genome Engineering Laboratory of Division of Plant Biotechnology, SKUAST-K during 2018-19.

\section{Plant material/explants}

Plants of tomato male sterile line Shalimar FMS-1 from the Experimental Field, Division of Vegetable Science and Polyhouse were selected for the explant collection (Mother Block) from disease free juvenile branches. For taking hypocotyl as explants, the seeds were germinated on half MS media in the Divisional Potato Tissue Culture Lab.

\section{Description of shalimar FMS-1}

(Accession No: IC 573425) used as female parent in the development of two tomato indeterminate hybrids viz., Shalimar Tomato Hybrid-1 and Shalimar Tomato Hybrid-2 with an outstanding yield of potential of 1320 quintals per hectare and 995 quintals per hectare respectively [3].

\section{Nutrient media}

MS (I-V) medium supplemented with $3 \%$ sucrose, 0.8 percent agar and different concentrations and combinations of calcium $\mathrm{D}$ pantothenate (CDP), calcium chloride $\left(\mathrm{CaCl}_{2}\right)$ and gibberellic acid $\left(\mathrm{GA}_{3}\right)$ were added as variables, then sterilized using an autoclave at $121^{\circ} \mathrm{C}$ and $1.05 \mathrm{~kg} / \mathrm{cm}^{2}$ (15 psi) for 20 minutes. And all the aseptic manipulations like surface sterilization, preparation and inoculation of explants were carried out. The cultures were generally incubated at $24 \pm 2{ }^{\circ} \mathrm{C}$ in an air conditioned culture room with a 16/8hour light/dark regime.

\section{Experimental parameters}

A variety of experiments were conducted during the present investigation aimed at the development of a protocol for in vitro propagation of tomato (Solanum lycopersicon) male sterile line Shalimar FMS-1. Details regarding the methodologies adopted are given in the sections that follow.

Experiment-1: Standardization of protocol for sterilizing the explants for in vitro micro propagation of tomato male sterile line (Shalimar FMS-1)

The success of plant tissue culture protocol depends on explant sterilization Selection of sterilizing agent and time period of exposure is also critical because the living material should not lose 


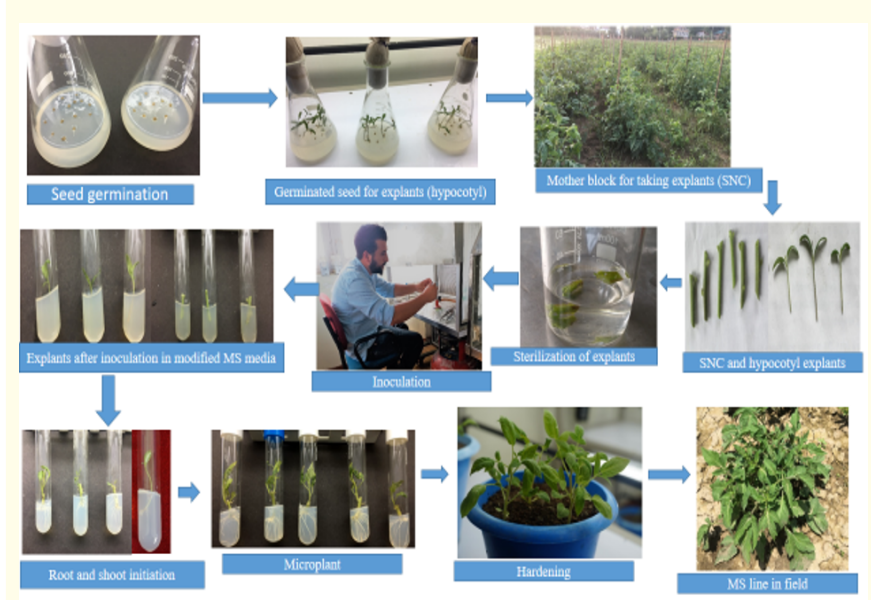

Figure 1: Main steps in micro propagation of tomato male sterile line (Shalimar FMS-1).

their biological activity and only contaminants should be eliminated during sterilization. Past investigations suggest that sodium hypochlorite ( $\mathrm{NaOCl}$ ) is the best choice for surface sterilization as it is readily available and can be diluted to proper concentrations. However, a balance between concentration and time must be determined empirically for each type of explant because of phytotoxicity. Ethanol is also used as powerful sterilizing agent but also extremely phytotoxic. Therefore, very short exposure of few minutes or seconds is generally given to explants. Surface sterilization with heavy metal salts is another way of sterilization in which Mercuric chloride $\left(\mathrm{HgCl}_{2}\right)$ is the famous one and always been a major choice but because of is toxicity and unsafe nature for both researcher and environment it is usually replace by other disinfectants. Details of surface sterilization procedure for explants are given in the following section.

\section{Single node cutting and hypocotyl segments}

Single node and hypocotyl segments were procured from the selected plants from vegetable field, polyhouse and the laboratory. These were separated with the help of a sharp scalpel. Explants on arrival in the laboratory were washed with running tap water 2 to 3 times and thereafter final 2 to 3 rinses with double distilled water.

For standardization of protocol for sterilization of explants (hypocotyl and single node cutting) the mercuric chloride and sodium hypochlorite for surface sterilization of explants were used as mercuric chloride @ 0.01\%,0.05\%,0.10\%,0.20\% and sodium hypochlorite @ 0.5\%,1.0\%,1.5\% for the time duration of 30,45 and 60 seconds totaling 21 treatment combinations.

Experiment- 2: Development of protocol for in vitro shoot and root regeneration in tomato male sterile line in a single medium

For developing a protocol for in vitro shoot and root regeneration (micro plant regeneration) of tomato male sterile line using various explants (hypocotyl and single node cutting), the treatment combinations were used as shown in table (Table 1).

\begin{tabular}{|c|c|c|c|c|c|}
\hline S. No. & Treatment & $\begin{array}{c}\text { Medium } \\
\text { Composition }\end{array}$ & $\begin{array}{c}\text { CDP } \\
(\mathrm{mg} / \mathrm{l})\end{array}$ & $\begin{array}{c}\mathrm{CaCl}_{2} \\
(\mathrm{mg} / \mathrm{l})\end{array}$ & $\begin{array}{c}\mathbf{G A}_{3} \\
(\mu \mathrm{g} / \mathrm{l})\end{array}$ \\
\hline 01. & $\mathrm{~T}_{1}$ & $\begin{array}{c}\text { MS salts }+3 \% \\
\text { Sucrose }+0.8 \% \\
\text { Agar }\end{array}$ & 1.50 & 352 & 300 \\
\hline 02. & $\mathrm{~T}_{2}$ & $\begin{array}{c}\text { MS salts }+3 \% \\
\text { Sucrose }+0.8 \% \\
\text { Agar }\end{array}$ & 1.50 & 352 & 400 \\
\hline 03. & $\mathrm{~T}_{3}$ & $\begin{array}{c}\text { MS salts }+3 \% \\
\text { Sucrose }+0.8 \% \\
\text { Agar }\end{array}$ & 1.50 & 352 & 500 \\
\hline 04. & $\mathrm{~T}_{4}$ & $\begin{array}{c}\text { MS salts }+3 \% \\
\text { Sucrose }+0.8 \% \\
\text { Agar }\end{array}$ & 1.50 & 440 & 300 \\
\hline 05. & $\mathrm{~T}_{5}$ & $\begin{array}{c}\text { MS salts }+3 \% \\
\text { Sucrose }+0.8 \% \\
\text { Agar }\end{array}$ & 1.50 & 440 & 400 \\
\hline 06. & $\mathrm{~T}_{6}$ & $\begin{array}{c}\text { MS salts }+3 \% \\
\text { Sucrose }+0.8 \% \\
\text { Agar }\end{array}$ & 1.50 & 440 & 500 \\
\hline 07. & $\mathrm{~T}_{7}$ & $\begin{array}{c}\text { MS salts }+3 \% \\
\text { Sucrose }+0.8 \% \\
\text { Agar }\end{array}$ & 1.50 & 528 & 300 \\
\hline 08. & $\mathrm{~T}_{8}$ & $\begin{array}{c}\text { MS salts }+3 \% \\
\text { Sucrose }+0.8 \% \\
\text { Agar }\end{array}$ & 1.50 & 528 & 400 \\
\hline 09. & $\mathrm{~T}_{9}$ & $\begin{array}{c}\text { MS salts }+3 \% \\
\text { Sucrose }+0.8 \% \\
\text { Agar }\end{array}$ & 1.50 & 528 & 500 \\
\hline 10. & $\mathrm{~T}_{10}$ & $\begin{array}{c}\text { MS salts }+3 \% \\
\text { Sucrose }+0.8 \% \\
\text { Agar }\end{array}$ & 2.00 & 352 & 300 \\
\hline
\end{tabular}




\begin{tabular}{|c|c|c|c|c|c|}
\hline 11. & $\mathrm{~T}_{11}$ & $\begin{array}{c}\text { MS salts }+3 \% \\
\text { Sucrose }+0.8 \% \\
\text { Agar }\end{array}$ & 2.00 & 352 & 400 \\
\hline 12. & $\mathrm{~T}_{12}$ & $\begin{array}{l}\text { MS salts }+3 \% \\
\text { Sucrose }+0.8 \% \\
\text { Agar }\end{array}$ & 2.00 & 352 & 500 \\
\hline 13. & $\mathrm{~T}_{13}$ & $\begin{array}{c}\text { MS salts }+3 \% \\
\text { Sucrose }+0.8 \% \\
\text { Agar }\end{array}$ & 2.00 & 440 & 300 \\
\hline 14. & $\mathrm{~T}_{14}$ & $\begin{array}{c}\text { MS salts }+3 \% \\
\text { Sucrose }+0.8 \% \\
\quad \text { Agar }\end{array}$ & 2.00 & 440 & 400 \\
\hline 15. & $\mathrm{~T}_{15}$ & $\begin{array}{c}\text { MS salts }+3 \% \\
\text { Sucrose }+0.8 \% \\
\text { Agar }\end{array}$ & 2.00 & 440 & 500 \\
\hline 16. & $\mathrm{~T}_{16}$ & $\begin{array}{c}\text { MS salts }+3 \% \\
\text { Sucrose }+0.8 \% \\
\quad \text { Agar }\end{array}$ & 2.00 & 528 & 300 \\
\hline 17. & $\mathrm{~T}_{17}$ & $\begin{array}{c}\text { MS salts }+3 \% \\
\text { Sucrose }+0.8 \% \\
\text { Agar }\end{array}$ & 2.00 & 528 & 400 \\
\hline 18. & $\mathrm{~T}_{18}$ & $\begin{array}{c}\text { MS salts }+3 \% \\
\text { Sucrose }+0.8 \% \\
\text { Agar }\end{array}$ & 2.00 & 528 & 500 \\
\hline 19. & $\mathrm{~T}_{19}$ & $\begin{array}{c}\text { MS salts }+3 \% \\
\text { Sucrose }+0.8 \% \\
\text { Agar }\end{array}$ & 2.50 & 352 & 300 \\
\hline 20. & $\mathrm{~T}_{20}$ & $\begin{array}{c}\text { MS salts }+3 \% \\
\text { Sucrose }+0.8 \% \\
\text { Agar }\end{array}$ & 2.50 & 352 & 400 \\
\hline 21. & $\mathrm{~T}_{21}$ & $\begin{array}{l}\text { MS salts }+3 \% \\
\text { Sucrose }+0.8 \% \\
\text { Agar }\end{array}$ & 2.50 & 352 & 500 \\
\hline 22. & $\mathrm{~T}_{22}$ & $\begin{array}{c}\text { MS salts }+3 \% \\
\text { Sucrose }+0.8 \% \\
\text { Agar }\end{array}$ & 2.50 & 440 & 300 \\
\hline 23. & $\mathrm{~T}_{23}$ & $\begin{array}{c}\text { MS salts }+3 \% \\
\text { Sucrose }+0.8 \% \\
\text { Agar }\end{array}$ & 2.50 & 440 & 400 \\
\hline 24. & $\mathrm{~T}_{24}$ & $\begin{array}{c}\text { MS salts }+3 \% \\
\text { Sucrose }+0.8 \% \\
\text { Agar }\end{array}$ & 2.50 & 440 & 500 \\
\hline 25. & $\mathrm{~T}_{25}$ & $\begin{array}{c}\text { MS salts }+3 \% \\
\text { Sucrose }+0.8 \% \\
\text { Agar }\end{array}$ & 2.50 & 528 & 300 \\
\hline
\end{tabular}

\begin{tabular}{|l|c|c|c|c|c|}
\hline 26. & $\mathrm{~T}_{26}$ & $\begin{array}{c}\text { MS salts }+3 \% \\
\text { Sucrose }+0.8 \% \\
\text { Agar }\end{array}$ & 2.50 & 528 & 400 \\
\hline 27. & $\mathrm{~T}_{27}$ & $\begin{array}{c}\text { MS salts }+3 \% \\
\text { Sucrose }+0.8 \% \\
\text { Agar }\end{array}$ & 2.50 & 528 & 500 \\
\hline
\end{tabular}

Table 1: Treatment combination detail for microplant regeneration.

$\mathrm{CDP}=$ Calcium D Pantothenate, $\mathrm{CaCl}_{2}=$ Calcium Chloride, $\mathrm{GA}_{3}=$ Gib berellic Acid.

Medium composition and concentration were based on preliminary studies.

\section{Results and Discussion}

The results of present investigation, “Development of a novel in-vitro Protocol for Micro propagation of Tomato Male Sterile Line (Shalimar FMS-1). are presented under the following headings and sub-headings.

Standardization of protocol for sterilizing the explants for in vitro micro propagation of tomato male sterile line (Shalimar FMS-1)

The explants hypocotyl and single node segments were subjected to twenty-one different sterilization regimes using Murashige and Skoog, 1962 (MS) as the basal medium. Effect of various sterilization regimes (concentration) and explants on percent survival and percent contamination (Table 2 ) was highly significant.

The highest mean percentage of survival to an extent of 96.29 and 86.11 percent was obtained by treating the explants (hypocotyl and single node cuttings) with sodium hypochlorite (1.0\%). The lowest mean survival percent of 33.33 and 55.55 percent was obtained by treating the explants (hypocotyl and single node cuttings) with mercuric chloride $0.20 \%$ and $0.01 \%$ respectively. Maximum percentage of surviving explants was 100 and 91.66 percent when the hypocotyl and single node cutting explants were treated with sodium hypochlorite (1.0\%) for 45 seconds respect-ively. The highest mean percent contamination to the extent of 54.65 and 56.93 percent was obtained by treating the explants (both hypocotyl and single node cuttings) with mercuric chloride $(0.01 \%)$. The lowest mean percent contamination to the extent 16.17 and 17.22 
percent was obtained by treating the explants (both hypocotyl and single node cuttings) with sodium hypochlorite (1.0\%). The lowest percent contamination of 11.92 and 12.22 percent was observed when the explants (both hypocotyl and single node cuttings) were treated with sodium hypochlorite 1.0 percent for 45 seconds. The present study on the effect of different surface sterilants and sterilization regimes revealed that maximum survival percentage $(100 \%$ for hypocotyl and $91.66 \%$ for single node cutting), minimum mortality percentage $(0.00 \%$ for hypocotyl and $8.33 \%$ for single node cutting) and least contamination (11.92\% in hypocotyl and $12.22 \%$ in single node cutting) was observed when both single node cutting and hypocotyl explants were treated with $1 \%$ sodium hypochlorite for 45 seconds (Table 2). These results are in close conformity with those of [4] in tomato, who found that the sterilization treatment with $2 \%$ hypochlorite for 10 minutes, $70 \%$ ethanol for 1 minute and $3.5 \%$ hypochlorite for 20 minutes without the ethanol treatment gave optimum sterilization of the explants of three tomato cultivars [5]; who reported treatment of explants with $5.25 \%$ sodium hypochlorite with tween 20 for 15 minutes proved effective surface sterilization procedure for maximum survival of explants with minimum tissue injury [6], who worked on development of efficient in vitro callus induction and plant regeneration protocol for different polish tomato cultivars and found that surface sterilization in $70 \%(\mathrm{v} / \mathrm{v})$ ethanol for 1 minute; then treatment in a $30 \%$ solution of commercial bleach containing $5.5 \%(\mathrm{w} / \mathrm{v})$ of sodium hypochlorite for 10 minutes proved efficient sterilization procedure and avoided contamination also.

Developing a protocol for in vitro shoot and root regeneration in a single medium

The results pertaining to effect of different media on root and shoot regeneration percentage, days to root, shoot and microplant initiation, root, shoot and microplant length (cm) (hypocotyl and single node cuttings) are presented in the tables 3 . Highest root regeneration percentage to the extent of 91.66 and 83.33 percent was obtained when the explants (both hypocotyl and single node cuttings) were cultured on $\mathrm{T}_{14}$ medium consisting of MS I-V medium supplemented with (calcium D pantothenate $2 \mathrm{mg} \mathrm{l}^{-1}+$ calcium chloride $440 \mathrm{mg} \mathrm{l}^{-1}+$ gibberellic acid $0.4 \mathrm{mg} \mathrm{l}^{-1}$ ), Lowest root regeneration percentage of 25 percent was obtained when hypocotyl explants were cultured on $\mathrm{T}_{2}, \mathrm{~T}_{3}, \mathrm{~T}_{13}$ and $\mathrm{T}_{20}$ medium respectively. The lowest root regeneration percentage of 8.33 percent was obtained from single node cuttings when cultured on $\mathrm{T}_{20}$ and $\mathrm{T}_{23}$ respectively.
The maximum days to root initiation 8 were observed when hypocotyl explants were cultured on $\mathrm{T}_{18}$ medium while in case of single node cuttings the maximum number of days to root initiation 15 were taken in medium $\mathrm{T}_{6}, \mathrm{~T}_{10}$, and $\mathrm{T}_{23}$ respectively. The minimum days to root initiation by explants were 3 in case of hypocotyl and 9 in case of single node cuttings and was observed in $\mathrm{T}_{14}$ medium. Highest root length to the tune of $7 \mathrm{~cm}$ and $6.40 \mathrm{~cm}$ in both hypocotyl and single node cuttings was observed on $\mathrm{T}_{14}$ medium whereas the length of roots was small $1.90 \mathrm{~cm}$ and $1.60 \mathrm{~cm}$ in hypocotyl and single node cuttings respectively when cultured on $\mathrm{T}_{13}$ medium. Highest shoot regeneration percentage to the extent of 91.66 and 83.33 percent was obtained when the explants (both hypocotyl and single node cuttings) were cultured on $\mathrm{T}_{14}$ medium consisting of MS I-V medium supplemented with (calcium D pantothenate $2 \mathrm{mg} \mathrm{l}^{-1}+$ calcium chloride $440 \mathrm{mg} \mathrm{l}^{-1}+$ gibberellic acid $0.4 \mathrm{mg} \mathrm{l}^{-1}$ ), Lowest shoot regeneration percentage of 16.66 percent was obtained when hypocotyl explants were cultured on $\mathrm{T}_{18}$ medium. The lowest root regeneration percentage of 8.33 percent was obtained from single node cuttings when cultured on $\mathrm{T}_{20}$ and $\mathrm{T}_{23}$ medium respectively. The maximum days to shoot initiation 11 were observed when hypocotyl explants were cultured on $\mathrm{T}_{23}$ medium while in case of single node cuttings the maximum number of days to shoot initiation 18 were taken in medium $\mathrm{T}_{10}, \mathrm{~T}_{20}$ and $\mathrm{T}_{23}$ respectively. The minimum days to shoot initiation by explants were 5 in case of hypocotyl and 11 in case of single node cuttings and was observed in $\mathrm{T}_{14}$ medium. Highest shoot length to the tune of $11 \mathrm{~cm}$ and 10.20 $\mathrm{cm}$ in both hypocotyl and single node cuttings was observed on $\mathrm{T}_{14}$ medium whereas the length of roots was small $2.0 \mathrm{~cm}$ and $1.70 \mathrm{~cm}$ in hypocotyl and single node cuttings respectively when cultured on $\mathrm{T}_{23}$ medium. The maximum days to microplant regeneration 23 were observed when hypocotyl explants were cultured on $\mathrm{T}_{23}$ medium while in case of single node cuttings the maximum number of days to microplant regeneration 28 were taken in medium $\mathrm{T}_{23}$. The minimum days to microplant regeneration by explants were 12 in case of hypocotyl and 17 in case of single node cuttings and was observed in $\mathrm{T}_{14}$ medium. Highest microplant length to the tune of $18 \mathrm{~cm}$ and $16.60 \mathrm{~cm}$ in both hypocotyl and single node cuttings was observed on $\mathrm{T}_{14}$ medium whereas the length of roots was small 4.0 $\mathrm{cm}$ and $3.30 \mathrm{~cm}$ in hypocotyl and single node cuttings respectively when cultured on $\mathrm{T}_{23}$ medium.

Various factors have been found to influence the induction of in vitro rooting and shooting in plant cell and tissue culture. Amongst 


\begin{tabular}{|c|c|c|c|c|c|c|c|c|c|c|c|c|c|c|c|c|}
\hline \multicolumn{9}{|c|}{ Survival percentage } & \multicolumn{8}{|c|}{ Contamination percentage } \\
\hline \multirow{3}{*}{$\begin{array}{l}\text { Treat- } \\
\text { ment/ } \\
\text { Concen- } \\
\text { tration }\end{array}$} & \multicolumn{3}{|c|}{ Hypocotyl } & \multirow{3}{*}{ Mean } & \multicolumn{3}{|c|}{ Single node cutting } & \multirow{3}{*}{ Mean } & \multirow{2}{*}{\multicolumn{3}{|c|}{$\begin{array}{c}\text { Hypocotyl } \\
\text { Time duration }\end{array}$}} & \multirow[b]{3}{*}{ Mean } & \multirow{2}{*}{\multicolumn{3}{|c|}{\begin{tabular}{|c|} 
Single node cutting \\
Time duration \\
\end{tabular}}} & \multirow[b]{3}{*}{ Mean } \\
\hline & \multicolumn{3}{|c|}{ Time duration } & & \multicolumn{3}{|c|}{ Time duration } & & & & & & & & & \\
\hline & $\begin{array}{c}\mathrm{t}_{1}: 30 \\
\text { sec }\end{array}$ & $\begin{array}{c}t_{2}: 45 \\
\text { sec }\end{array}$ & $\begin{array}{c}t_{3}: 60 \\
\text { sec }\end{array}$ & & \begin{tabular}{|c|}
$t_{1}: 30$ \\
sec
\end{tabular} & $\begin{array}{c}\mathbf{t}_{2}: 45 \\
\text { sec }\end{array}$ & $\begin{array}{c}t_{3}: 60 \\
\mathrm{sec}\end{array}$ & & $\begin{array}{c}t_{1}: 30 \\
\text { sec }\end{array}$ & \begin{tabular}{|c}
$t_{2}: 45$ \\
sec
\end{tabular} & \begin{tabular}{|c}
$t_{3}: 60$ \\
sec
\end{tabular} & & $\begin{array}{c}t_{1}: 30 \\
\text { sec }\end{array}$ & $\begin{array}{c}\mathbf{t}_{2}: 45 \\
\text { sec }\end{array}$ & \begin{tabular}{|c}
$t_{3}: 60$ \\
sec
\end{tabular} & \\
\hline $\begin{array}{l}\mathrm{C}_{1}: \\
\text { Mercuric } \\
\text { chloride @ } \\
0.01 \% \\
\end{array}$ & $\begin{array}{l}66.66 \\
(8.21)\end{array}$ & $\begin{array}{l}58.33 \\
(7.69)\end{array}$ & $\begin{array}{l}66.66 \\
(8.21)\end{array}$ & $\begin{array}{l}63.88 \\
(8.04)\end{array}$ & $\begin{array}{l}50.00 \\
(7.12)\end{array}$ & $\begin{array}{l}58.33 \\
(7.69)\end{array}$ & $\begin{array}{l}58.33 \\
(7.69)\end{array}$ & $\begin{array}{l}55.55 \\
(7.50)\end{array}$ & $\begin{array}{l}49.47 \\
(7.09)\end{array}$ & $\begin{array}{l}52.38 \\
(7.30)\end{array}$ & $\begin{array}{l}62.10 \\
(7.94)\end{array}$ & $\begin{array}{l}54.65 \\
(7.44)\end{array}$ & $\begin{array}{l}61.27 \\
(7.88)\end{array}$ & $\begin{array}{l}52.38 \\
(7.30)\end{array}$ & $\begin{array}{l}57.14 \\
(7.59)\end{array}$ & $\begin{array}{r}56.93 \\
(7.59)\end{array}$ \\
\hline $\begin{array}{l}\mathrm{C}_{2}: \\
\text { Mercuric } \\
\text { chloride @ } \\
0.05 \%\end{array}$ & $\begin{array}{l}58.33 \\
(7.69)\end{array}$ & $\begin{array}{l}50.00 \\
(7.07)\end{array}$ & $\begin{array}{l}50.00 \\
(7.07)\end{array}$ & $\begin{array}{l}52.77 \\
(7.28)\end{array}$ & $\begin{array}{l}66.66 \\
(8.21)\end{array}$ & $\begin{array}{l}58.33 \\
(7.69)\end{array}$ & $\begin{array}{l}66.66 \\
(8.21)\end{array}$ & $\begin{array}{l}63.88 \\
(8.04)\end{array}$ & $\begin{array}{l}52.38 \\
(7.30)\end{array}$ & $\begin{array}{l}50.00 \\
(7.14)\end{array}$ & $\begin{array}{l}50.00 \\
(7.14)\end{array}$ & $\begin{array}{l}50.79 \\
(7.19)\end{array}$ & $\begin{array}{l}49.47 \\
(7.09)\end{array}$ & $\begin{array}{l}47.62 \\
(6.96)\end{array}$ & $\begin{array}{l}41.60 \\
(6.52)\end{array}$ & $\begin{array}{r}46.23 \\
(6.86)\end{array}$ \\
\hline $\begin{array}{l}{ }_{3}: \\
\text { Mercuric } \\
\text { hloride @ } \\
.10 \%\end{array}$ & $\begin{array}{l}50.00 \\
(7.12)\end{array}$ & $\begin{array}{l}58.33 \\
(7.69)\end{array}$ & $\begin{array}{l}50.00 \\
(7.12)\end{array}$ & $\begin{array}{l}52.77 \\
(7.31)\end{array}$ & $\begin{array}{l}75.00 \\
(8.70)\end{array}$ & $\begin{array}{c}66.66 \\
(8.21)\end{array}$ & $\begin{array}{l}83.33 \\
(9.17)\end{array}$ & $\begin{array}{l}75.00 \\
(8.70)\end{array}$ & $\begin{array}{l}40.63 \\
(6.36)\end{array}$ & $\begin{array}{l}34.52 \\
(5.89)\end{array}$ & $\begin{array}{l}16.98 \\
(4.23)\end{array}$ & $\begin{array}{l}30.71 \\
(5.49)\end{array}$ & $\begin{array}{l}36.94 \\
(6.15)\end{array}$ & $\begin{array}{l}28.96 \\
(5.46)\end{array}$ & $\begin{array}{l}23.16 \\
(4.90)\end{array}$ & $\begin{array}{r}29.69 \\
(5.50)\end{array}$ \\
\hline $\begin{array}{l}C_{4}: \\
\text { Mercuric } \\
\text { chloride @ } \\
0.20 \%\end{array}$ & $\begin{array}{l}33.33 \\
(5.83)\end{array}$ & $\begin{array}{l}41.66 \\
(6.51)\end{array}$ & $\begin{array}{l}25.00 \\
(5.05)\end{array}$ & $\begin{array}{l}33.33 \\
(5.79)\end{array}$ & $\begin{array}{l}58.33 \\
(7.69)\end{array}$ & $\begin{array}{l}66.66 \\
(8.21)\end{array}$ & $\begin{array}{l}50.00 \\
(7.12)\end{array}$ & $\begin{array}{l}58.33 \\
(7.67)\end{array}$ & $\begin{array}{l}47.77 \\
(6.93)\end{array}$ & $\begin{array}{l}26.11 \\
(5.18)\end{array}$ & $\begin{array}{l}36.11 \\
(6.03)\end{array}$ & $\begin{array}{l}36.66 \\
(6.05)\end{array}$ & \begin{tabular}{|l|}
42.06 \\
$(6.54)$
\end{tabular} & \begin{tabular}{|l|}
49.47 \\
$(7.09)$
\end{tabular} & $\begin{array}{l}49.04 \\
(7.05)\end{array}$ & $\begin{array}{l}46.86 \\
(6.89)\end{array}$ \\
\hline $\begin{array}{l}\mathrm{C}_{5}: \text { Sodium } \\
\text { hypochlo- } \\
\text { rite @ } \\
0.50 \% \\
\end{array}$ & $\begin{array}{l}58.33 \\
(7.69)\end{array}$ & $\begin{array}{l}66.66 \\
(8.21)\end{array}$ & $\begin{array}{l}66.66 \\
(8.21)\end{array}$ & $\begin{array}{l}63.88 \\
(8.04)\end{array}$ & $\begin{array}{l}75.00 \\
(8.70)\end{array}$ & $\begin{array}{l}66.66 \\
(8.21)\end{array}$ & $\begin{array}{l}66.66 \\
(8.18)\end{array}$ & $\begin{array}{l}69.44 \\
(8.36)\end{array}$ & $\begin{array}{l}42.65 \\
(6.56)\end{array}$ & $\begin{array}{l}41.60 \\
6.52)\end{array}$ & $\begin{array}{l}49.47 \\
(7.09)\end{array}$ & $\begin{array}{l}44.57 \\
(6.72)\end{array}$ & $\begin{array}{l}55.18 \\
(7.49)\end{array}$ & $\begin{array}{l}49.47 \\
(7.09)\end{array}$ & $\begin{array}{l}63.05 \\
(8.00)\end{array}$ & $\begin{array}{r}55.90 \\
(7.52)\end{array}$ \\
\hline $\begin{array}{l}\mathrm{C}_{6}: \text { Sodium } \\
\text { hypochlo- } \\
\text { rite @ } \\
1.0 \%\end{array}$ & $\begin{array}{l}91.66 \\
(9.62)\end{array}$ & $\begin{array}{l}100.00 \\
(10.05)\end{array}$ & $\begin{array}{l}97.22 \\
(9.90)\end{array}$ & $\begin{array}{l}96.29 \\
(9.85)\end{array}$ & $\begin{array}{l}83.33 \\
(9.17)\end{array}$ & $\begin{array}{l}91.66 \\
(9.62)\end{array}$ & $\begin{array}{l}83.33 \\
(9.15)\end{array}$ & $\begin{array}{l}86.11 \\
(9.31)\end{array}$ & $\begin{array}{l}13.89 \\
(3.82)\end{array}$ & $\begin{array}{l}11.92 \\
(3.56)\end{array}$ & $\begin{array}{l}22.72 \\
(4.85)\end{array}$ & $\begin{array}{l}16.17 \\
(4.08)\end{array}$ & $\begin{array}{l}19.46 \\
(4.46)\end{array}$ & $\begin{array}{l}12.22 \\
(3.61)\end{array}$ & $\begin{array}{l}20.00 \\
(4.50)\end{array}$ & $\begin{array}{l}17.22 \\
(4.19)\end{array}$ \\
\hline \begin{tabular}{|l|}
$\mathrm{C}_{7}:$ Sodium \\
hypochlo- \\
rite @ \\
$1.5 \%$ \\
\end{tabular} & $\begin{array}{l}58.33 \\
(7.69)\end{array}$ & $\begin{array}{l}50.00 \\
(7.12)\end{array}$ & $\begin{array}{l}41.66 \\
(6.51)\end{array}$ & $\begin{array}{l}50.00 \\
(7.10)\end{array}$ & $\begin{array}{l}58.33 \\
(7.69)\end{array}$ & $\begin{array}{l}66.66 \\
(8.21)\end{array}$ & $\begin{array}{l}66.66 \\
(8.21)\end{array}$ & $\begin{array}{l}63.88 \\
(8.04)\end{array}$ & $\begin{array}{l}33.13 \\
(5.83)\end{array}$ & $\begin{array}{l}23.65 \\
(4.83)\end{array}$ & $\begin{array}{l}26.11 \\
(5.18)\end{array}$ & $\begin{array}{l}27.63 \\
(5.28)\end{array}$ & $\begin{array}{l}42.06 \\
(6.54)\end{array}$ & \begin{tabular}{|l}
62.10 \\
$(7.94)$
\end{tabular} & $\begin{array}{l}49.47 \\
(7.09)\end{array}$ & $\begin{array}{l}51.21 \\
(7.19)\end{array}$ \\
\hline Mean & $\begin{array}{l}59.52 \\
(7.69)\end{array}$ & $\begin{array}{l}60.71 \\
(7.76) \\
\end{array}$ & $\begin{array}{l}56.74 \\
(7.44)\end{array}$ & & $\begin{array}{l}66.66 \\
(8.18)\end{array}$ & $\begin{array}{l}67.85 \\
(8.26)\end{array}$ & $\begin{array}{l}67.85 \\
(8.25) \\
\end{array}$ & & $\begin{array}{l}39.71 \\
(6.23)\end{array}$ & $\begin{array}{l}34.59 \\
(5.81)\end{array}$ & $\begin{array}{l}37.64 \\
(6.06)\end{array}$ & & \begin{tabular}{|l|}
43.78 \\
$(6.59)$ \\
\end{tabular} & $\begin{array}{l}43.17 \\
(6.49)\end{array}$ & $\begin{array}{l}43.35 \\
(6.52)\end{array}$ & \\
\hline & $\begin{array}{l}\text { Cor } \\
\text { Tir }\end{array}$ & $\begin{array}{r}C D(p \leq \\
\text { centratio } \\
\text { e durati } \\
C \times t:\end{array}$ & $\begin{array}{l}0.05) \\
\text { on (C): } 0 . \\
\text { ons }(t): 1 \\
: \text { NS }\end{array}$ & $\begin{array}{l}0.61 \\
\text { NS }\end{array}$ & $\begin{array}{l}\text { Conc } \\
\text { Tim }\end{array}$ & $\begin{array}{r}\mathrm{CD}(\mathrm{p} \leq \\
\text { centratio } \\
\text { e durati } \\
\mathrm{Cxt}\end{array}$ & $\begin{array}{l}\leq 0.05) \\
\text { on (C): } \\
\text { ions ( }(t) \\
\text { : NS }\end{array}$ & & & $\begin{array}{r}\mathrm{CD}(\mathrm{p} \\
\text { centrati } \\
\text { ne durat } \\
\mathrm{C} \times \mathrm{t}\end{array}$ & $\begin{array}{l}0 \leq 0.05) \\
\text { ion }(\mathrm{C}) \text { : } \\
\text { tions }(\mathrm{t}) \\
: 1.15\end{array}$ & & & $\begin{array}{r}C D(p s \\
\text { entrati } \\
\text { durati } \\
C x t:\end{array}$ & $\begin{array}{l}\leq 0.05) \\
\text { ion }(\mathrm{C}) \text { : } \\
\text { tions }(\mathrm{t}) \\
: 0.86\end{array}$ & \\
\hline
\end{tabular}

Table 2: Effect of different sterilization treatments on survival and contamination percentage of explants (hypocotyl and single node cutting) of tomato male sterile line Shalimar FMS-1.

Values under parenthesis are square root transformed values. 


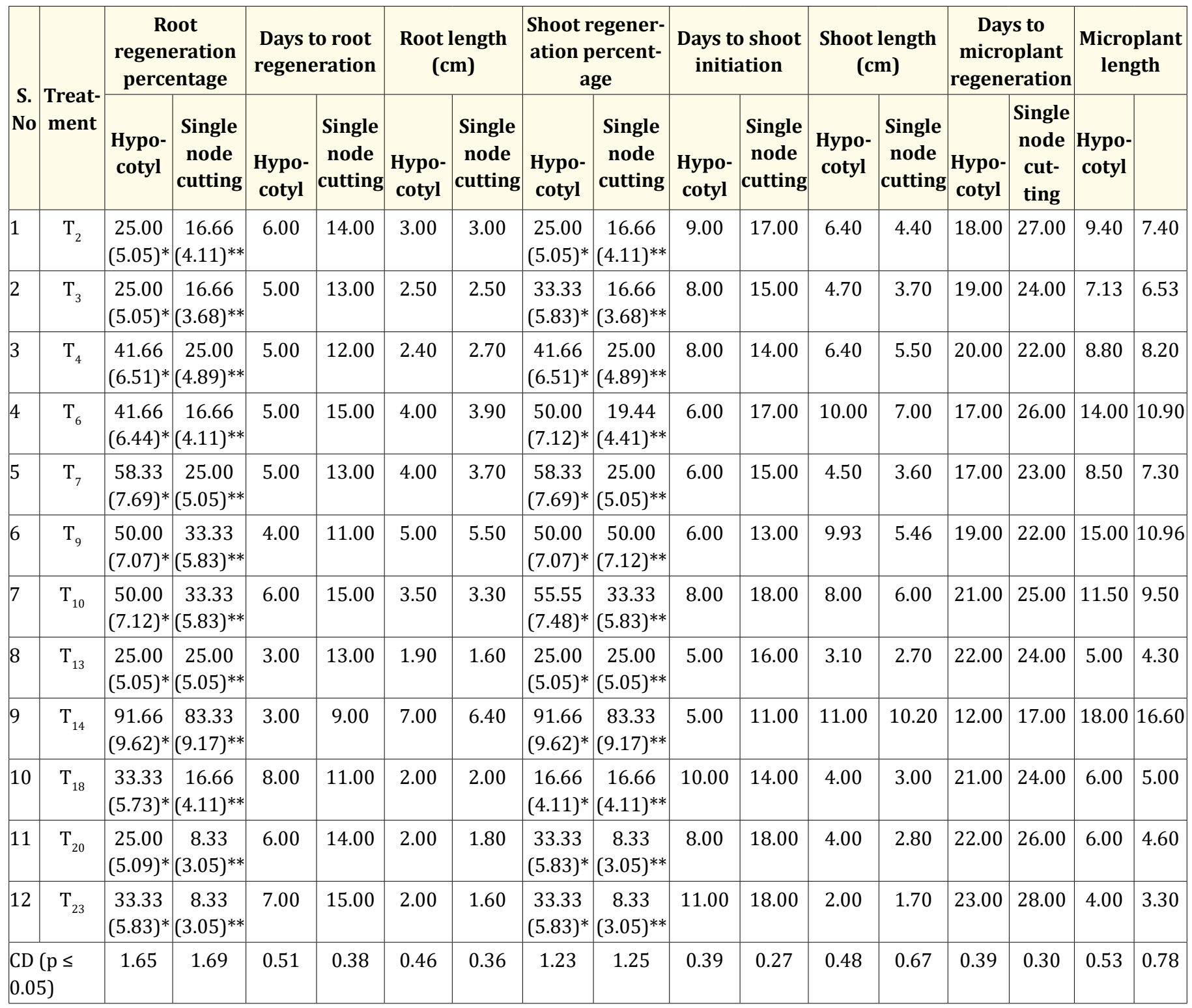

Table 3: Effect of various modified MS media on root, shoot and microplant regeneration \%, days to root and shoot regeneration, root, shoot and microplant length.

* Values under parenthesis are square root transformed values.

** Values under parenthesis are arcsine transformed values.

these, the choice of growth medium, concentration and combination of growth regulators, and explants type are prominent ones and play a major role in standardizing a regeneration protocol for a plant species/cultivar [7]. The first step of initiating of in vitro rooting and shooting is to successfully adapt the plant tissue or explant to heterotrophic mode of nutrition (establishment stage). The culture establishment medium is useful for adaptation and stimulation of initial growth of explants and their subsequent development in microplants. Different types of nutrient media have been used for Solanum species tissue culture [8]. Out of the differ- 
ent types of nutrient media (Woody Plant medium, Gresshoff medium) used for Solanum species tissue culture, MS medium has been found to be quite satisfactory for the micropropagation of Solanum species. In present study modified MS medium also proved to be satisfactory for the establishment, shooting and rooting of tomato male sterile line Shalimar FMS-1 using single node cutting and hypocotyl as explants.

In the present study, in vitro root and shoot regeneration leading to complete microplant development of tomato male sterile line (Shalimar FMS-1) in a single culture medium with the treatment combination of $\mathrm{T}_{14}$ (MS I-V medium supplemented with CDP @ $2 \mathrm{mg} / \mathrm{l}+\mathrm{CaCl}_{2} @ 44 \mathrm{mg} / \mathrm{l}+\mathrm{GA}_{3} @ 0.4 \mathrm{mg} / \mathrm{l}$.) is reported. Among the different modified MS media having different combinations of growth regulators (calcium D pantothenate, calcium chloride, gibberellic acid), $\mathrm{T}_{14}$ medium MS I-V medium supplemented with CDP @ $2 \mathrm{mg} / \mathrm{l}+\mathrm{CaCl}_{2} @ 44 \mathrm{mg} / \mathrm{l}+\mathrm{GA}_{3} @ 0.4 \mathrm{mg} / \mathrm{l}$. resulted in highest percentage of rooting $91.66 \%$ for hypocotyl and $83.33 \%$ for single node cutting), minimum days to root initiation (3 days in hypocotyl and 9 days in single node cutting), maximum root length $(7.00 \mathrm{~cm}$ in hypocotyl and $6.40 \mathrm{~cm}$ in single node cutting), highest shoot regeneration (91.66\% in hypocotyl and $83.33 \%$ in single node cutting), minimum days to shoot initiation (5 days in hypocotyl and 11 days in single node cutting), maximum shoot length $(11 \mathrm{~cm}$ in hypocotyl and $10.20 \mathrm{~cm}$ in single node cutting), minimum days to microplant regeneration (12 in hypocotyl and 17 in single node cutting), maximum microplant length $(18 \mathrm{~cm}$ in hypocotyl and $16.60 \mathrm{~cm}$ in single node cutting. Among the twenty-seven different growth regulator combinations in basal MS media, only twelve treatment combinations $\left(\mathrm{T}_{2}, \mathrm{~T}_{3}, \mathrm{~T}_{4}, \mathrm{~T}_{6}, \mathrm{~T}_{7}, \mathrm{~T}_{9}, \mathrm{~T}_{10}, \mathrm{~T}_{13}, \mathrm{~T}_{14}, \mathrm{~T}_{18}, \mathrm{~T}_{20}\right.$, $\mathrm{T}_{23}$.) proved successful in culture establishment of explants while fifteen treatment combinations $\left(\mathrm{T}_{1}, \mathrm{~T}_{5}, \mathrm{~T}_{8}, \mathrm{~T}_{11}, \mathrm{~T}_{12}, \mathrm{~T}_{15}, \mathrm{~T}_{16}, \mathrm{~T}_{17}, \mathrm{~T}_{19}\right.$, $\mathrm{T}_{21}, \mathrm{~T}_{22}, \mathrm{~T}_{24}, \mathrm{~T}_{25}, \mathrm{~T}_{26}, \mathrm{~T}_{27}$. f failed to evoke any response in terms of root and shoot initiation and microplant development.

Current work elucidates that sodium hypochlorite is more suitable surface sterilant than mercuric chloride as it resulted in maximum survival percentage, minimum mortality percentage and minimum contamination percentage of explants. Similar results have been obtained by [9-11] for sterilization of potato sprouts and shoot tips. Explant type has been found to significantly influence the regeneration response leading to complete microplant development in vitro. Micropropagation of Solanum species has been achieved using different explants viz., leaves [12-14] hypocotyl $[13,15,16]$, Cotyledon [17-19] and inflorescence [20]. In the present study two types of explants viz., single node cutting and hypocotyl were used. The advantage with the single node cutting is that large number of explants can be taken from a single seed which develops in to a single plant while only a single hypocotyl segment can be taken from a single seed which drastically reduces the cost of in vitro microplant development of male sterile line. However, the main advantage with using hypocotyl is that it takes only 12 days for complete microplant development. Single node cutting with sub culturing is therefore recommended for micropropagation of male sterile line in tomato as it is economic as compared to using hypocotyl as explants.

\section{Conclusion}

From the study it is concluded that, various sterilization treatments yielded aseptic cultures but the sterilization regime of (1.0\%) sodium hypochlorite gave highest percentage of aseptic cultures, highest percentage of surviving explants, minimum mortality and minimum contamination percentage. The percent survival response of hypocotyl explants was significantly higher than the single node cutting explants and their percent contamination was significantly lower than the single node cuttings. $\mathrm{T}_{14}$ medium consisting of MS I-V medium supplemented with (calcium D pantothenate $2 \mathrm{mg} \mathrm{l}^{-1}+$ calcium chloride $44 \mathrm{mg} \mathrm{l}^{-1}+$ gibberellic acid $0.4 \mathrm{mg} \mathrm{l}^{-1}$ ) gave highest rooting percentage, minimum number of days to root initiation, maximum root length, gave highest shooting percent, minimum days to shoot initiation, maximum shoot length and highest microplant height, minimum days to microplant regeneration, maximum microplant diameter and maximum microplant weight. This shows that constituents of the medium especially the growth regulators have significant effect on the regeneration potential of explants. The shooting percent, rooting percent response of hypocotyl explants was significantly higher than the single node cutting explants. This shows that the morphogenetic response of different explants even from the same plant may vary.

\section{Bibliography}

1. National Horticulture Board. 2017- 2018 Press Information Bureau Government of India, Ministry of Agriculture 2023.

2. Anonymous. "Area production and productivity of tomato in India”. Department of Agriculture, Government of India (2016).

Citation: Syed Mazahir., et al. "Development of a Novel In-vitro Protocol for Micro propagation of Tomato Male Sterile Line (Shalimar FMS-1) of Kashmir Valley India". Acta Scientific Agriculture 5.4 (2021): 61-69. 
3. Kouser P Wani., et al. "Hybrid seed production of important kharief vegetable crops- a practical guide". (2017): 3.

4. Ajenifujah-Solebo S., et al. "Tissue culture regeneration of three Nigerian cultivars of tomatoes". African Journal of Plant Science 6.14 (2012): 370-375.

5. Osman Magdoleen G., et al. "Callus formation and organogenesis of tomato (Lycopersicon esculentum Mill, C.V. Omdurman) induced by thidiazuron". African Journal of Biotechnology 9.28 (2010): 4407-4413.

6. Aneta Gerszberg., et al. "Efficient in Vitro Callus Induction and Plant Regeneration Protocol for Different Polish Tomato Cultivars". Notulae Botanicae Horti Agrobotanaceae 44.2 (2016): 452-458.

7. El-Farash., et al. "Genotype, explant age and explant type as effecting callus and shoot regeneration in tomato". Assian Journal of Agricultural Sciences 24 (1993): 3-14.

8. Gjuleva and Atanasov. "Micropropagation of Platanus acerifolia in vitro, silvae genetica" (1993).

9. Miller S A and Lipschutz L. Potato in: Ammirato P.V., Evans, D., Sharp W. R. and Yamada Yasuguki (eds.), Handbook of plant tissue culture, New York. McMillan publishing company 3 (1984): 291-293.

10. Naik PS and Chandra R. "Use of tissue culture technique in crop improvement with special reference to potato". CPRI, Shimla (1993).

11. Villafranca M J., et al. "Effect of physiological age of mother tuber and number of subcultures on in vitro tuberization of potato (Solanum tuberosum L.)". Plant Cell Reports 17 (1998): 787-790.

12. Dwivedi Srivastava., et al. "Direct regeneration of shoots from leaf segments of tomato (Lycopersicon esculentum) cultured in-vitro and production of plants". Indian Journal of Experimental Biology 28 (1990): 32-35.

13. Davis., et al. "Callus initiation and regeneration of tomato ( $L y$ copersicon esculentum) cultivars with different sensitivities to metribuzin". Plant Growth Regulators Society of America 22 (1994): 65-73.
14. Duzyaman., et al. "Comparative studies on regeneration of different tissues of tomato in vitro". Acta Horticulture (1994): 235-242.

15. Plastira and Perdikaris. "Effect of genotype and explant type in regeneration frequency of tomato in vitro". Acta Horticulture (1997): 231-234.

16. Venkatachalam P., et al. "High frequency plantlet regeneration from hypocotyl explants of tomato (Lycopersicon esculentum Mill.) via organogenesis". Plant Cell Biotechnology Molecular Biology 1 (2000): 95-100.

17. Ye ZB., et al. "In vitro culture of tomato cotyledons and regenerated plants". Journal of Huazhong Agricultural University 13 (1994): 291-295.

18. Ichimura $\mathrm{K}$ and Oda M. "Stimulation of phenotypically normal shoot regeneration of tomato (Lycopersicon esculentum Mill.) by commercial filter paper extract". Journal of Japanese Society. Horticultural Science 67 (1998): 378-380.

19. Ramiah and Rajappan. "Direct shoot regeneration from excised cotyledonary leaf of tomato". South Indian Horticulture 44 (1996): 101-102.

20. Compton and Veilleux. "Shoot, root and flower morphogenesis on tomato inflorescence explants". Plant Cell Tissue and Organ Culture 24 (1991): 223-231.

\section{Assets from publication with us}

- Prompt Acknowledgement after receiving the article

- Thorough Double blinded peer review

- Rapid Publication

- Issue of Publication Certificate

- High visibility of your Published work

Website: www.actascientific.com/

Submit Article: www.actascientific.com/submission.php

Email us: editor@actascientific.com

Contact us: +919182824667 